\title{
Sintesis dan Karakterisasi Hidrogel Superabsorben Berbasis Asam Akrilat Hasil Iradiasi Gamma
}

\section{Synthesis and Characterization of Acrylic Acid Based- Superabsorbent Hydrogel Using Gamma Irradiation}

\author{
Erizal $^{1}$, Marisa Lana ${ }^{2}$, R. Setyo A.K. ${ }^{1}$, dan Basril Abbas ${ }^{1}$ \\ ${ }^{1}$ Pusat Aplikasi Isotop dan Radiasi, BATAN, \\ Jl. Lebak Bulus Raya No. 49 Jakarta Selatan 12440 \\ ${ }^{2}$ Fakultas Farmasi dan Sains Universitas Muhammadiyah Prof. Dr. Hamka \\ Jl. Delima II/IV, Klender Jakarta Timur 13460 \\ Email : erizal@batan.go.id
}

Diterima 09-12-2014; Diterima dengan revisi 17-03-2015; Disetujui 06-05-2015

\begin{abstract}
ABSTRAK
Sintesis dan Karakterisasi Hidrogel Superabsorben Berbasis Asam Akrilat Hasil Iradiasi Gamma. Dalam kerangka mendapatkan hidrogel dengan kemampuan menyerap air yang relatif tinggi, telah dilakukan sintesis hidrogel superabsorben (HSA) berbasis asam akrilat menggunakan teknik radiasi. Satu seri larutan asam akrilat dengan derajat netralisasi (Dn) 0 ; 0,$20 ; 0,40 ; 0,60 ; 0,80$ dan 1 masing-masing diiradiasi sinar gamma pada dosis10 kGy (laju dosis $5 \mathrm{kGy} / \mathrm{j})$. Pengaruh derajat netralisasi terhadap nisbah pengembung hidrogel dipelajari. Sifat termal hidrogel diukur menggunakan Differential scanning calorymetry (DSC). Perubahan struktur kimia hidrogel diukur menggunakan Fourier transform infra red (FTIR), dan morfologi hidrogel diobservasi menggunakan Scanning electron microscope (SEM). Hasil eveluasi menunjukan bahwa pada kondisi optimum (Dn=0,80, $10 \mathrm{kGy}, 20$ menit), hidrogel menunjukkan kemampuan menyerap air yang relatif tinggi $(\sim 600 \mathrm{~g} / \mathrm{g})$. Hasil pengukuran DSC mengkonfirmasi kemungkinan terbentuknya jenis produk akhir hasil iradiasi asam akrilat. Spektra FTIR menunjang bahwa reaksi polimerisasi asam akrilat melalui ikatan rangkap dua dalam struktur molekul asam akrilat. Hasil pengujian SEM menunjukkan bahwa hidtogel berpori ukuran makro.
\end{abstract}

Kata kunci : Hidrogel, superabsorben, asam akrilat, irradiasi, derajat netralisasi.

\begin{abstract}
Synthesis and Characterization of Acrylic Acid Based-Superabsorbent Hydrogel Using Gamma Irradiation. The main aim of this work was to obtain hydrogels with higher water absorption, synthesis of superabsorbent hydrogels based on acrylic acid using gamma irradiation have been carried out. A series of acrylic acid solutions with different neutralization degree $(\mathrm{Dn})$ in the range of $0-1$ were irradiated using gamma irradiation at a dose of $10 \mathrm{kGy}$ (dose rate $5 \mathrm{kGy} / \mathrm{h}$ ) at room temperature. The effect of neutralization degree on swelling ratio were studied. Thermal properties of hydrogels were examined using Differential scanning calorymetry (DSC). The chemical changes of hydrogels were measured using Fourier transform infra red (FTIR). The morphology of hydrogels were observed using Scanning electron microscope (SEM). After evaluated, it was found that the hydrogels had an optimum swelling conditions $(10 \mathrm{kGy}, 20 \mathrm{~min}, \mathrm{Dn}=0.80)$ with high swelling capacity $\sim 600 \mathrm{~g} / \mathrm{g}$. Thermogram DSC confirmed the possibility of end products of irradiated acrylic acid types. Spectra FTIR supported the role of acrylic acid double bonds in polymerization reactions. Morphology of SEM showed a large numbers of macropores in the network of hydrogels.
\end{abstract}

Key words : Hydrogel, superabsorbent, acrylic acid, irradiation, neutralization degree. 


\section{PENDAHULUAN}

Hidrogel superabsorben (HSA) merupakan salah satu bahan baku yang penting karena kemampuannya dapat menyerap air atau cairan dalam jumlah yang relatif besar. HSA didefinisikan sebagai hidrogel berikatan silang dengan struktur 3 dimensi yang dapat menyerap air/cairan minimal $100 \mathrm{x}$ berat keringnya dan tidak larut dalam air. Jika hidrogel direndam dalam air dan menyerap air, maka bentuknya berubah mirip air. HSA pada awalnya berasal dari Amerika Serikat yang digunakan sebagai kantong air di bidang pertanian, selanjutnya dikembangkan di Jepang pada pertengahan tahun 1970 untuk keperluan produk yang higenis seperti wadah bedah (surgical pad), pengemas panas dan dingin (hot and cold theraphy packs), pengendap limbah rumah sakit (medical waste solidification), popok bayi (disposable diapers), kertas saniter (sanitary napkins) dll. [1]. Selain itu, HSA dapat digunakan sebagai tanah atifisial untuk mengkondisikan tanah, bahan sebagai pembawa obat di bidang farmasi dan beberapa kegunaan lainnya [2-12].

Dalam penelitian ini digunakan monomer asam akrilat sebagai bahan dasar pembuatan HSA. Asam akrilat dengan rumus molekul $\mathrm{CH}_{2} \mathrm{CHCOOH}$ merupakan asam lemah yang terionisasi dalam air menjadi bentuk anion karboksilat $\left(-\mathrm{CH}_{2} \mathrm{CHOO}\right)$ dan berkemampuan mengikat air yang kuat melalui ikatan hidogen. Oleh karena itu, jika asam akrilat disintesis menjadi hidrogel dan direndam dalam air, maka gugus anion-anion pada rantai jaringan polimer akan berinteraksi dengan pelarut atau polimer, rantai polimer tersebut akan tolak menolak satu dengan lainnya dan terjadi ekpansi dari koil polimer yang mengakibatkan air yang diserap meningkat. Oleh karena demikian pentingnya gugus anion asam akrilat dalam kemampuan menyerap air, maka untuk menjaga agar anion tersebut berfungsi dengan sempurna pada umumnya dilakukan netralisasi asam akrilat sebelum proses sintesis menjadi hidrogel [12].

Polimerisasi asam akrilat dapat dilakukan dengan beragam metode termasuk proses kimia dan induksi teknik radiasi. Proses teknik radiasi relatif lebih mudah dibandingkan kimia. Keunggulan aplikasi radiasi antara lain prosesnya mudah dikontrol, sintesis dan sterilisasi dapat berlangsung secara simultan dalam satu tahap proses, tidak dibutuhkan inisiator dan crosslinker. Hal tersebut yang menyebabkan irradiasi merupakan sebagai metode pilihan yang terbaik pada preparasi hidrogel [13]. Beberapa peneliti telah melaporkan sintesis radiasi asam akrilat untuk membuat hidrogel [14-16]. Namun demikian hanya sedikit sekali informasi yang berkaitan dengan sifat pengembung dan karakteristik hidrogel asam akrilat dinetralkan sebagian yang telah dipublikasikan [17-18]. Oleh karena itu, untuk mengoptimalkan kegunaan asam akrilat sebagai hidrogel dan menunjang informasi seperti yang dideskripsi pada hal-hal tersebut diatas, maka dalam penelitian ini dilakukan investigasi sifat pengembung dan karakteristik hidrogel hasil iradiasi berbasis asam akrilat dinetralkan sebagian. Satu seri larutan asam akrilat yang dinetralkan menggunakan natrium hidroksida $(\mathrm{NaOH})$ dengan derajat netralisasi 0 hingga 1 diiradiasi gamma pada dosis $10 \mathrm{kGy}$. Sifat pengembung dan karakteristik hidrogel hasil iradiasi dipelajari. Pengembung hidrogel ditentukan secara gravimetri. Karakteristik sifat termal hidrogel diukur menggunakan Differential Scanning calorymetry (DSC), Perubahan struktur kimia hidrogel diukur menggunakan Fourier transform infra red (FTIR), dan morfologi hidrogel diamati menggunakan Scanning electron microscope (SEM).

\section{BAHAN DAN METODE}

\section{Bahan}

Asam akrilat (AA), natrium hidroksida $(\mathrm{NaOH})$ buatan Merck. Air suling dipakai 
sebagai pelarut dalam penelitian ini. Bahan kimia lainnya yang dipakai berkualitas p.a.

\section{Alat}

Untuk mengkonfirmasi produk akhir hidrogel dilakukan uji sifat termal menggunakan Differential Scanning Calorymetry (DSC) Shimadzu 60, buatan Jepang. Hidrogel kering hasil iradiasi dengan berat $\pm 5 \mathrm{mg}$ dimasukkan ke dalam tempat sampel (pan) alumunium dipres dengan alat crimper. Selanjutnya dimasukkan ke dalam pemanas DSC sebagai reference digunakan tempat sampel alumunium dengan bentuk dan ukuran yang sama dengan sampel. Pemanasan dilakukan hingga suhu $600{ }^{\circ} \mathrm{C}$ dengan laju pemanasan $10^{\circ} \mathrm{C} /$ menit.

Karakteristik permukaan hidrogel dipelajari menggunakan Scanning Electron Microscope (SEM) JSM (Jeol, Jepang) pada voltase $30 \mathrm{kV}$. Hidrogel dalam bentuk kering direndam dalam air suling hingga menggembung maksimum ( \pm 24 jam), selanjunya dikeringkan menggunakan freeze dryer pada suhu $-107{ }^{\circ} \mathrm{C}$ ( \pm 48 jam). Selanjutnya hidrogel kering dilapisi dengan lapisan tipis campuran emas palladium. Kemudian dilakukan pengamatan struktur porinya menggunakan SEM.

Perubahan struktur kimia hidrogel diukur menggunakan Fourier Transform infra red (FTIR), Shimadzu IR-Prestige-21 spectrometer model 8000 series, buatan Jepang. Hidrogel kering hasil iradiasi dalam bentuk serbuk dicampur dengan $\mathrm{KBr}$ dalam perbandingan \pm 1:200. Selanjutnya dilakukan pengukuran spektrum pada rentang bilangan gelombang $4000 \mathrm{~cm}^{-1}-400$ $\mathrm{cm}^{-1}$ dengan jumlah bilangan scan 20 ,

\section{Sintesis hidrogel dengan induksi iradiasi}

Asam akrilat dinetralkan sebagian menggunakan $\mathrm{NaOH}$ dengan derajat netralisasi yang beragam. Derajat netralisasi disingkat dengan simbol Dn adalah menyatakan persen mol asam akrilat yang dinetralkan oleh $\mathrm{NaOH}$. Satu seri larutan 15 $\mathrm{ml}(\sim 0,20 \mathrm{~mol})$ asam akrilat masing-masing dinetralkan (persen mol) dengan $\mathrm{NaOH}$ sebesar $0 \%(\mathrm{Dn}=0), 20 \%(\mathrm{Dn}=0,20), 40 \%$ $(\mathrm{Dn}=0,40), 60 \%(\mathrm{Dn}=0,60), 80 \% \quad(\mathrm{Dn}=0,8)$ dan $100 \%(\mathrm{Dn}=1)$. Campuran selanjutnya diaduk pada kecepatan $200 \mathrm{rpm}$ pada suhu kamar hingga homogen. Kemudian, larutan dituangkan ke dalam kantong plastik polipropilen (PP) ukuran $3 \times 10 \mathrm{~cm}^{2}$, diseal, dan lalu diiradiasi pada dosis 10 kGy (laju dosis $5 \mathrm{kGy} / \mathrm{j}$ ) pada suhu kamar. Hidrogel hasil iradiasi dikering-vakum pada suhu 60 ${ }^{\circ} \mathrm{C}$ hingga berat konstan. Selanjutnya hidrogel digiling mengunakan blender hingga ukuran 60-80 mesh.

\section{Pengujian nisbah pengembung hidrogel}

Laju pengembung hidrogel ditetapkan secara gravimetri. Hidrogel kering (Wo) dengan berat $\pm 0,10$ gr dimasukkan ke dalam $100 \mathrm{~mL}$ air suling, lalu diaduk dengan kecepatan $400 \mathrm{rpm}$ selang waktu detik atau menit pada suhu kamar. Selang waktu tertentu, hidrogel yang telah pengembung disaring menggunakan saringan teh $1 \pm 200$ mesh). Kemudian air saringan yang keluar dari saringan ditampung dalam beaker selang waktu $\pm 1 \mathrm{jam})$. hingga tidak ada lagi air yang menetes. Volume air yang tertampung dalam beaker ditimbang/diukur $\left(\mathrm{W}_{1}\right)$. Nisbah pengembung hidrogel dihitung dengan persamaan berikut :

Nisbah pengembung $=\left(\mathrm{W}_{\mathrm{t}} / \mathrm{Wo}_{\mathrm{O}}\right) / \mathrm{W}_{\mathrm{O}} \ldots$ (1)

Wo $=$ berat hidrogel kering awal, $\mathrm{W}_{1}=$ berat hidrogel dalam keadaan pengembung dalam waktu tertentu. Semua pengerjaan dilakukan secara triplo.

\section{HASIL DAN PEMBAHASAN}

\section{Produk utama hasil induksi iradiasi gamma asam akrilat yang dinetralkan sebagian}

Tahap utama dari penelitian ini adalah netralisasi asam akrilat menggunakan $\mathrm{NaOH}$ untuk melindungi gugus anion karboksilat hidrogel agar dapat berfungsi sebagai pengikat air ketika direndam dalam air. Selanjutnya asam akrilat yang dinetralkan 
sebagian diiradiasi dengan sinar gamma untuk menghasilkan hidrogel. Proses yang terjadi selama asam akrilat mengalami paparan iradiasi adalah melalui tahapantahapan yang umumnya terjadi seperti tahapan inisiasi, propagasi, dan terminasi
Oleh karena itu, jika dipapari iradiasi gamma akan dihasilkan produk utamanya adalah polimer berantai lurus homopolimer asam akrilat melalui reaksi addisi secara umum. Reaksi pembetukannya adalah seperti Gambar 1.

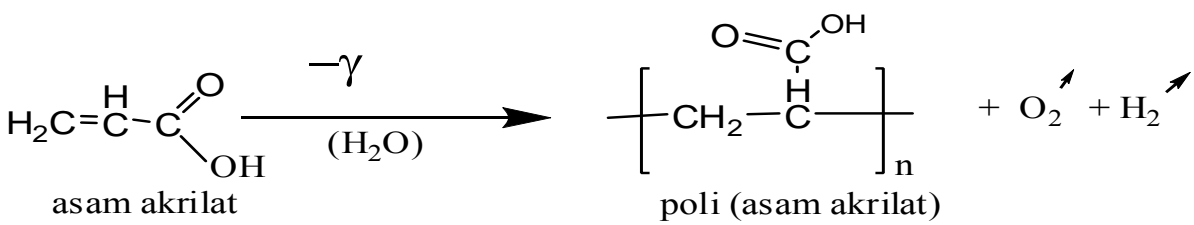

Gambar1. Reaksi induksi iradiasi polimerisasi poli (asam akrilat)

yang tahapan ini juga sama terjadi pada proses kimia. Pada tahapan terminasi akan dihasilkan produk yang dapat berupa homopolimer, kopolimer, dan produk degradasi serta produk hasil samping seperti peroksida dan gas $\mathrm{O}_{2}$ dan $\mathrm{H}_{2}$ [19]. Pada umumnya produk akhir hasil iradiasi asam akrilat yang dinetralkan sebagian melalui proses iradiasi sama seperti halnya hasil
Asam akrilat yang dinetralkan dengan nilai $\mathrm{Dn}=1$ yang berarti seluruh molekul asam akrilat diubah menjadi natrium asam akrilat, jika pada larutan ini dipapari iradiasi gamma akan dihasilkan produk utamanya adalah polimer berantai lurus dari garam poli natrium akrilat. Reaksi pembetukkannya adalah sebagai seperti Gambar 2.

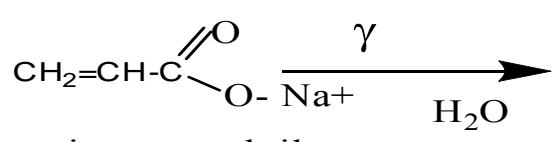

anion asam akrilat

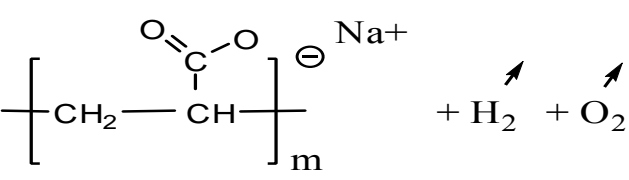

poli (natrium as am akrilat)

Gambar 2. Reaksi induksi iradiasi polimerisasi poli (natrium akrilat)

proses kimia sintesis hidrogel asam akrilat menggunakan inisiator dan crosslinker [20]. Berdasarkan hal tersebut yang sejalan dengan reaksi polimerisasi kimia secara umum, maka dapatlah diramalkan kemungkinan produk akhir hasil iradiasi asam akrilat. Asam akrilat yang dinetralkan sebagian dengan nilai $\mathrm{Dn}=0$ yang berarti dalam larutannya hanya terdiri dari molekul-molekul asam akrilat dan air. Ikatan rangkap dua pada asam akrilat merupakan bagian yang berfungsi dalam proses reaksi dan peka terhadap iradiasi.
Sedangkan asam akrilat yang dinetralkan dengan nilai Dn adalah 0,20; 0,$40 ; 0,60$ dan 0,80 yang berarti didalam masing-masing larutannya terdiri dari spesies aktif molekul-molekul asam akrilat dan molekul anion asam akrilat selain air dalam keadaan kesetimbangan dengan reaksinya adalah seperti Gambar 3.

Pada kondisi campuran ini yang terdiri dari 2 jenis molekulyang berbeda dan dalam hal ini maka ikatan rangkap berfungsi sebagai pusat reaksi. Oleh karena iu, jika pada larutan tersebut dipapari iradiasi 


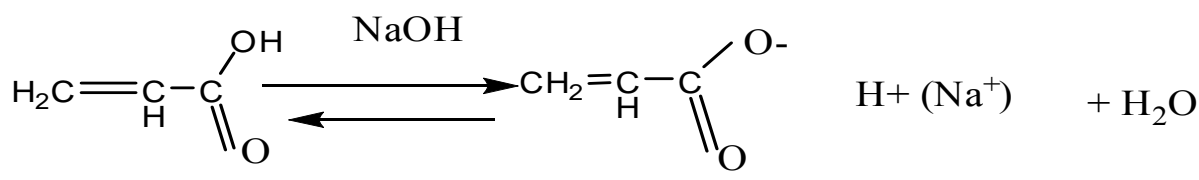

Asam akrilat

anion asam akrilat

Gambar 3. Reaksi kesetimbangan asam akrilat -anion asam akrilat

gamma, maka produk utama yang akan dihasilkan dari masing-masing asam akrilat dengan nilai Dn yang berbeda adalah polimer berikatan silang kopolimer (natrium akrilat-asam akrilat) dengan 3 kemungkinan bentuk stereokimianya yaitu bentuk sindiotattik, atatik dan isotatik [21]. Reaksi pembetukkannya adalah seperti Gambar 4. melebar pada suhu dekomposisi $426,63^{\circ} \mathrm{C}$. Berdasarkan interprestasi karakteristik thermogram DSC pada umumnya [22], dapatlah diduga kuat bahwa hidrogel kering dengan nilai $\mathrm{Dn}=0$ bentuk kristal homopolimer asam akrilat (reaksi 1) serta hidrogel kering dengan $\mathrm{Dn}=1$ berupa bentuk semi kristal homopolimer poli<smiles>C=CC(=O)O</smiles>

asam akrilat

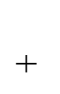<smiles></smiles>

natrium akrilat

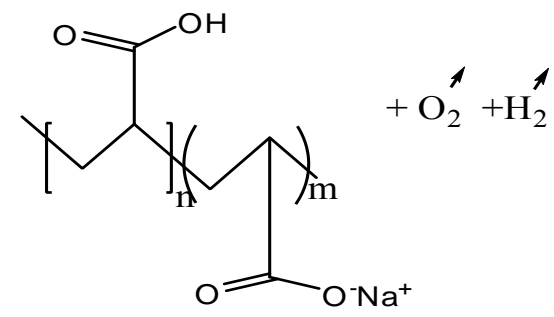

Kopoli (asam akrilat-Natrium akrilat)

Gambar 4. Reaksi induksi iradiasi kopolimerisasi asam akrilat-natrium akrilat

\section{Karakterisasi hidrogel menggunakan DSC}

Dalam kerangka untuk membuktikan dan mengkorfimasi kemungkinan hasil akhir produk hasil iradiasi seperti hal yang diasumsikan dan dijelaskan pada persamaan reaksi-reaksi tersebut diatas, maka dilakukan uji termal hidrogel kering asam akrilat dengan nilai Dn dari 0-hingga 1. Pada Gambar 5 a dan $b$ disajikan thermogram DSC hidrogel kering hasil iradiasi asam akrilat dengan nilai Dn 0 dan 1. Terlihat bahwa thermogram yang dihasilkan dari hidrogel dengan nilai $\mathrm{Dn}=0$ berupa 1 puncak tunggal tajam hasil proses exothermal pada suhu dekomposisi 461,30 ${ }^{\circ} \mathrm{C}$ dan thermogram hidrogel dengan nilai $\mathrm{Dn}=1$ nampak sebagai puncak tunggal yang natrium akrilat (reaksi 2). Sedangkan thermogram DSC hidrogel kering dengan nilai Dn secara berturut-turut 0,$20 ; 0,40$; 0,60 dan 0,60 dan 0,80 masing-masing nampak dengan 2 puncak dekomposisi yang melebar dan terpisah disajikan pada Gambar 5 (b), (c), (d), (e), (f) dan suhu dekomposisinya disajikan pada Tabel 1 . Untuk menjelaskan jenis 2 puncak dekomposisi thermogram DSC asam akrilat tersebut belum didapatkan informasi yang berkaitan dengan penelitian ini, karena beberapa penelitian yang telah dilakukan hanya menginformasikan karakteristik pengembung dan kinetiknya $[19,23,24]$. Oleh karena itu, untuk menjelaskan timbulnya 2 puncak dekomposisi tersebut adalah berdasarkan asumsi bahwa larutan 

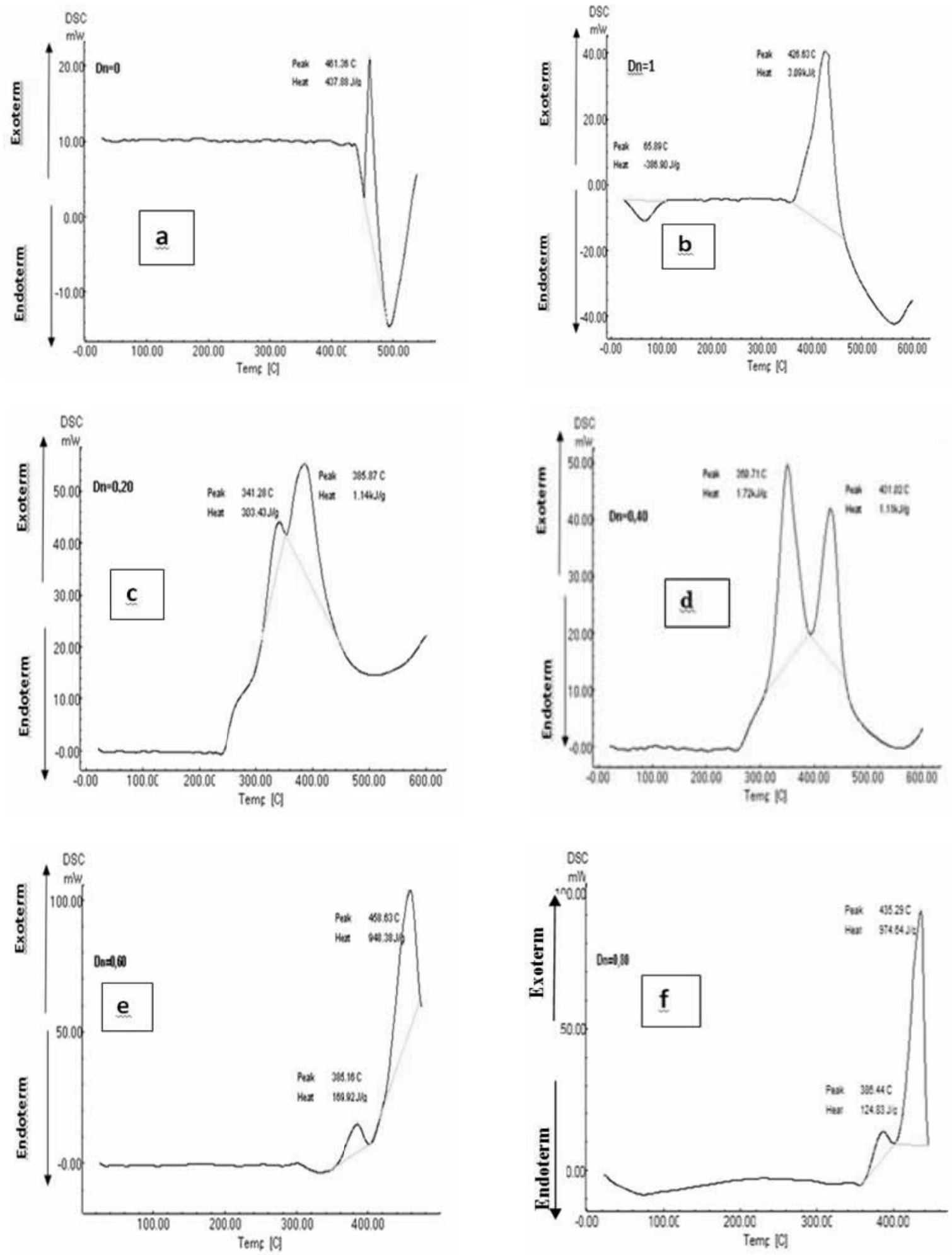

Gambar 5. Thermogram DSC hidrogel asam akrilat yang dinetralkan sebagian hasil iradiasi gamma dengan nilai Dn, a) 0, b) 1, c) 0,20, d) 0,40, e) 0,60 dan f) 0,80.

asam akrilat yang dinetralkan sebagian tesebut terdiri dari campuran spesies aktif molekul asam akrilat dan anion karboksilat asam akrilat. Oleh karena itu jika larutan ini diiradiasi menggunakan sinar gamma, maka ikatan rangkap dua pada asam akrilat 
Tabel 1. Suhu dekomposisi hidrogel kering hasil iradiasi netralisasi asam akrilat pada beragam nilai Dn

\begin{tabular}{ccc}
\hline \multirow{2}{*}{ Nilai Dn asam akrilat } & \multicolumn{2}{c}{ Suhu Dekomposisi $\left({ }^{\circ} \mathrm{C}\right)$} \\
\cline { 2 - 3 } & $(1)$ & $(2)$ \\
\hline 0 & 461,36 & - \\
0,20 & 341,28 & 385,87 \\
0,40 & 350,71 & 431,02 \\
0,60 & 385,16 & 458,63 \\
0,80 & 386,44 & 435,29 \\
1 & 426,63 & - \\
\hline
\end{tabular}

atau anionnya sebagai berperan penting pada jenis produk yang akan dihasilkan. Pada umumnya reaksi radikal polimerisasi baik pada monomer atau polimer terjadi secara acak (random), maka ditinjau dari stereokimianya dapatlah diperkirakan 3 jenis produk yang paling mungkin dihasilkan hasil iradiasi pada asam akrilat yang dinetralkan sebagaian yaitu kopolimer asam akrilat dalam bentuk sindiotatik, atatik dan isotatik [21]. CHAPIRO [19] melaporkan bahwa bentuk sindiotaktik dan atatik adalah 2 jenis produk yang mungkin diperoleh hasil polimerisasi asam akrilat yang dinetralkan sebagian pada proses dengan laju reaksi yang relatif tinggi. Berdasarkan asumsi tersebut, dapatlah diduga kuat bahwa 2 puncak dekomposisi hidrogel kering asam akrilat dinetralkan sebagian seperti yang disajikan pada Gambar 5 (b), (c), (d), (e), (f) merupakan puncak dekomposisi hidrogel kering asam akrilat berbentuk sindiotatik dan atatik struktur makromolekulnya atau bentuk lain yang perlu dilakukan penelitian lebih lanjut.

\section{Spektrum FTIR hidrogel}

Spektrum FTIR yang mewakili hidrogel asam akrilat hasil netralisasi sebagian dan diiradiasi gamma diisajikan pada Gambar 6. Terlihat bahwa terdapat pita absorbsi yang melebar pada daerah bilangan gelombang $3700-3000 \mathrm{~cm}^{-1}$ yang menunjukkan vibrasi ulur gugus $\mathrm{OH}$, vibrasi ulur gugus $-\mathrm{CH}$ pada punggung rantai hidrogel asam akrilat terdapat di daerah

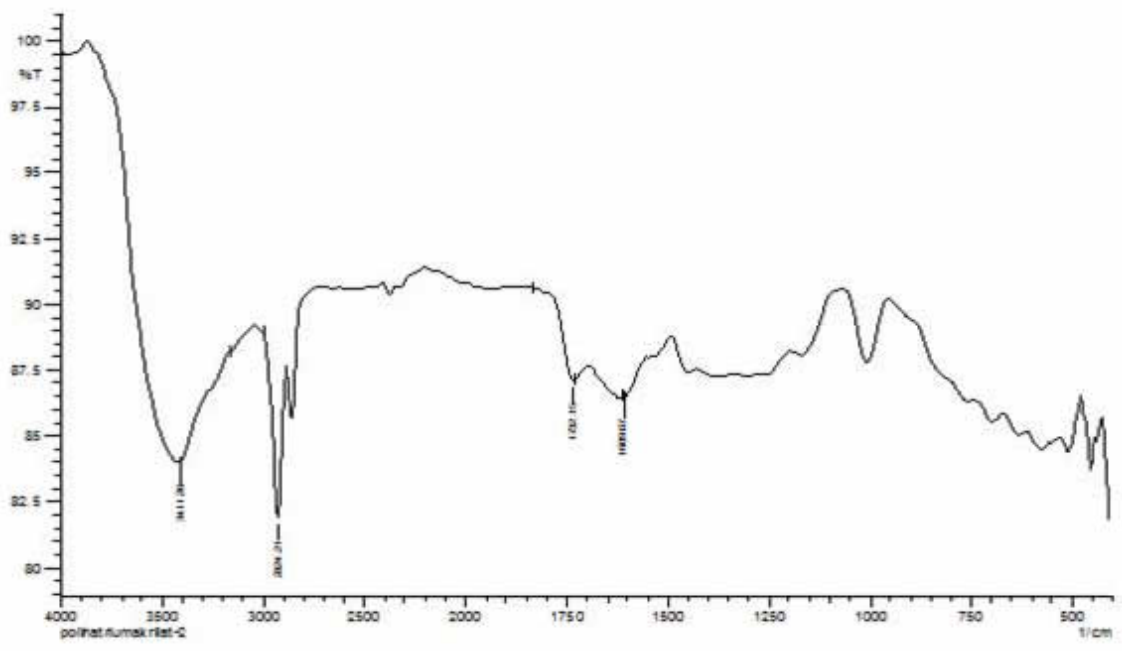

Gambar 6. Spektrum infra merah hidrogel asam akrilat hasil iradiasi gamma 
bilangan gelombang $2934 \mathrm{~cm}^{-1}$. Puncak absorbsi vibrasi deformasi gugus $-\mathrm{C}-\mathrm{OH}$ terletak pada daerah bilangan gelombang $1609 \mathrm{~cm}^{-1}$ menunjukkan vibrasi asimetris gugus - $\mathrm{COO}$. Hal yang sama juga diperoleh oleh Tomar dkk. [25].

\section{SEM hidrogel}

Foto SEM hidrogel pada umumnya memberikan informasi mengenai geometri pori-pori dan ukurannya pada lokasi yang spesifik. Oleh karena itu, foto SEM memberikan informasi yang relevan yang berkatian dengan homogenitas dan heterogenitas jaringan hidrogel. Untuk tujuan tersebut, Hasil foto SEM permukaan dan bagian dalam (interior) hidrogel dengan $\mathrm{Dn}=0,80$ bernilai rasio pengembung yang relatif tinggi $(\sim 1000 \mathrm{~g} / \mathrm{g})$ disajikan pada Gambar 7. Terlihat bahwa permukaan hidrogel terdiri dari pori-pori yang tidak teratur dengan kisaran ukuran pori 15-35 $\mu \mathrm{m}$, dan di beberapa lokasi dilingkupi oleh kulit tebal polimer. Kulit tebal polimer tersebut kemungkinan disebabkan oleh runtuhnya permukaan pori pada proses freeze dryng khususnya oleh pori yang besar dan kulit dinding hidrogel.

\section{Pengaruh waktu perendaman terhadap pengembung hidrogel}

Pengaruh waktu (detik) perendaman dalam air suling terhadap kinetika pengembung hidrogel asam akrilat yang dinetralkan pada nilai rentang Dn 0-1 hasil iradiasi disajikan pada Gambar 8. Terlihat bahwa rasio pengembung optimum 600 g/g dapat dicapai oleh hidrogel dengan nilai $\mathrm{Dn}=0,80$ selama waktu perendaman hingga 1200 detik (20 menit). Hidrogel dengan nilai Dn- 0 dan $\mathrm{Dn}=1$ dapat menyerap air yang relatif kecil $\sim 150 \mathrm{~g} / \mathrm{g}$ yang merupakan homopolimer pada hakikatnya larut dalam air. Hal ini mungkin disebabkan adanya sebagian kecil produk asam akrilat berikatan silang dalam ke dua homopolimer tersebut yang dapat menyerap dan mempertahankan air dalam jaringannya, Hal ini mengindikasikan juga bahwa asam akrilat yang dinetralkan dengan nilai $\mathrm{Dn}=0$ dan $\mathrm{Dn}=1$ merupakan polimer berantai lurus.

Sedangkan relatif tingginya nisbah pengembung hidrogel dengan nilai Dn pada rentang $0,20-0,80$ hal ini disebabkan struktur geometrinya yang berupa sindiotatik dan atatik dari hasil polimerasam induksi iradiasi asam akrilat. Pada $\mathrm{Dn}=0,80$ terjadi tolak menolak gugus fungsi anion

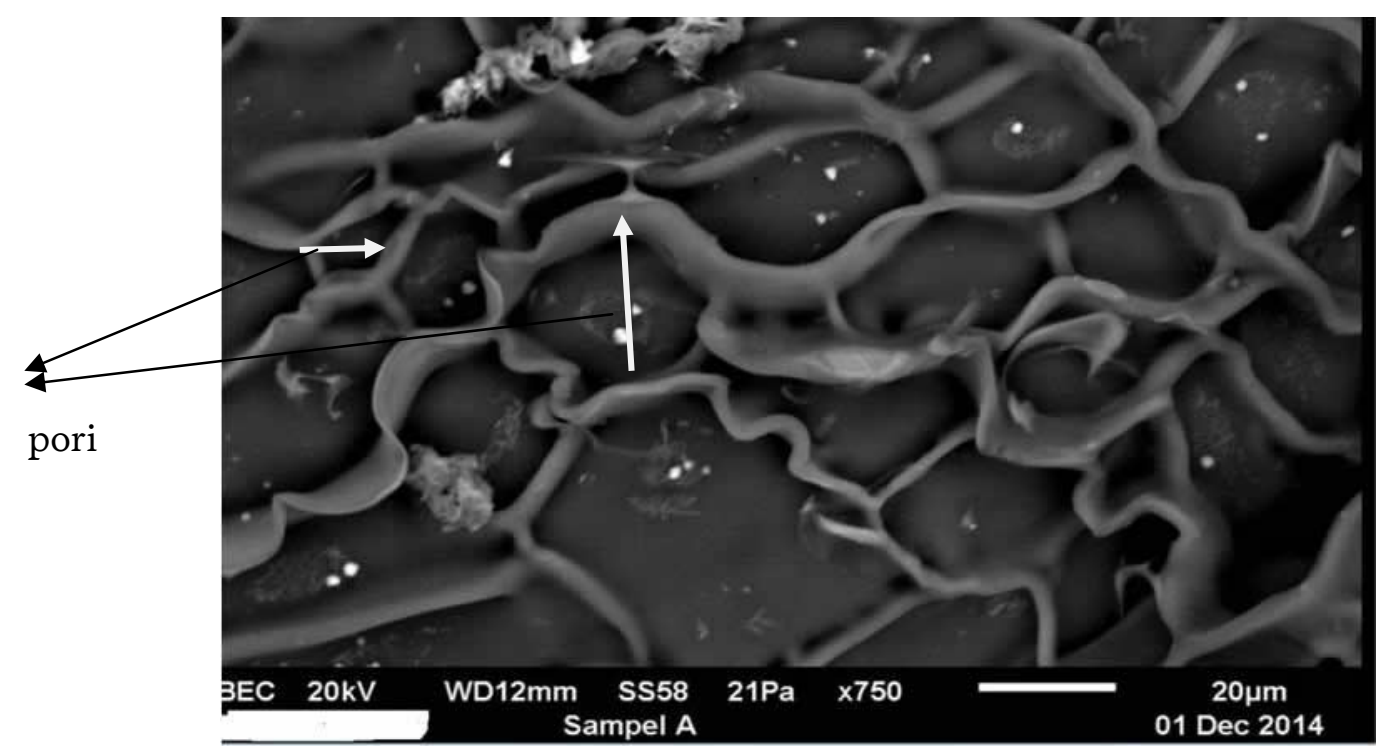

Gambar 7. Fotomikrograph hidrogel asam akrilat dengan nilai $\mathrm{Dn}=0.80$ yang diukur setelah mengembung maksimum dengan perbesaran $750 \mathrm{x}$. 
karboksilat dalam struktur jaringan hidrogel yang relatif besar dibandingkan hidrogel dengan nilai $\mathrm{Dn}=0,20,0,40$, dan 0,60 yang menyebabkan nisbah pengembungnya tinggi atau sebab lain yang perlu diteliti lebih lanjut. Hal ini juga mengindikasikan bahwa hidrogel asam akrilat yang dinetralkan dengan nilai Dn rentang 0,20-0,80 merupakan polimer berikatan silang. Hal yang sama juga dilaporkan oleh TONG dkk [24] yaitu bahwa nisbah pengembung hidrogel poliakrilat hasil netralisasi sebagian, nisbah pengembung meningkat dengan meningkatnya derajat netralisasi > 0,50 . kering hidrogel dengan nilai $\mathrm{Dn}=0,80$ hasil iradiasi berkemampuan menyerap air 600 gr air yang dicapai dalam waktu 20 menit. Hidrogel hasil netralisasi asam akrilat dengan nilai Dn pada rentang 0,20-0,80 menunjukkan nisbah pengembung yang relatif besar dibandingkan hidrogel dengan nilai Dn 0 dan 1. Berdasarkan thermogram DSC dan didukung nilai nisbah pengembung hidrogel, maka dapatlah diduga kuat bahwa hidrogel dengan derajat netralisasi 0 dan 1 berbentuk homopolimer, sedangkan hidrogel dengan nilai Dn dalam rentang 0,20-0,80 berbentuk kopolimer sindiotatik dan atatik.

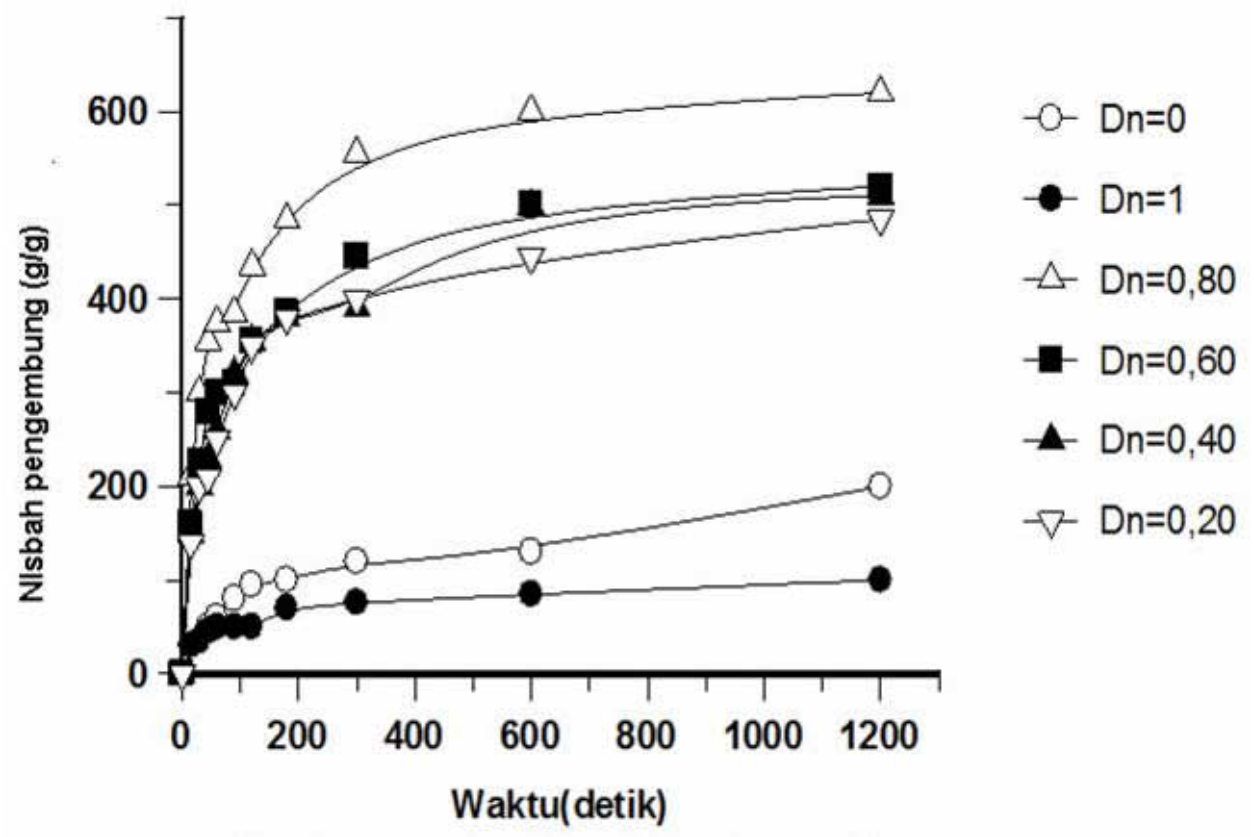

Gambar 8. Kinetika pengembung (detik) hidrogel asam akrilat yang dinetralkan sebagian hassil iradiasi gamma

\section{KESIMPULAN}

Hidrogel superabsorbent (HSA) dengan kemampuan menyerap air yang relatif tinngi telah berhasil disintesis menggunakan teknik iradiasi polimerisasi pada dosis 10 kGy dari larutan asam akrilat yang dinetralkan sebagian dengan $\mathrm{NaOH}$. Hasil penelitian menunjukkan bahwa 1 gr berat

\section{UCAPAN TERIMA KASIH}

Ucapan terima kasih disampaikan pada rekan-rekan di fasilitas Iradiator Karet (IRKA) bidang Fasilitas radiasi, PATIRBATAN yang telah membantu iradiasi sampel dalam penelitian ini. 


\section{DAFTAR PUSTAKA}

1. F.L. BUCHOLZ, T. GRAHAM, "Modern Superabsorbent Polymer Technology", Wiley-VCH, New York, 151 (1998).

2. H.A. ABD EL-REHIM, E.S.A., HEGAZY, H.L. ABD EL MOHDY, Radiation synthesis of hydrogels to enhance sandy soil, water retention and increase plant performance, J. Apply Polym Sci, 93, 1360-137 (2004).

3. M. BAKASS, A. MOKHLISSE, M. LALLEMAN, Absorption and desorption of liquid water by a superabsorbent polymer, Effect of polymer in the drying of the soil and quality of certain plants, $J$. Appl. Polym. Sci., 83, 234-243 (2002).

4. E. KARADAG, D. SARAYDIN, Y. CALDIRAN, O. GUVEN, Swelling studies of copolymeric acrylamide/crotonic acid hydrogels as carriers for agricultural uses, Polymer for Advanced Technologies, 11, 59-68 (2000).

5. A. SANNINO, A. ESPOSITO, A. DE ROSA, A. COZZOLINO, L. AMBROSIO, L. NICOLAS, Biomedical application of superabsorbent hydrogel for body water elimination in the treament of edemas, J. Biomed. Mater. Res. A, 67, 1016-1024 (2003).

6. C. CHANG, B. DUAN, J. CAI, L. ZHANG, Superabsorbent hydrogel based on cellulose for smart pengembung and controllable delivery, European Polymer Journal, 46, 92-100 (2010).

7. $\mathrm{H}$.

HOSSEINZADEH

POURJAVAVDI, M. ZOHURIAAN, 2-Hydrolized crosslinked kappa
carrageenan-g-PAAM as a novel smart superabsorbent hydrogel with low salt sensitivity, J. Biomater. Sci., Polym. Ed., 15, 1499-1511 (2004).

8. A.T. PAULINO, R.A. GUILORME, G.M. COMPESSE, E.Z. MUNIZ, J. NOZAKI, Removal of methylene blue from an aqueous media using superabsorbent hydrogel supported on modified polysaccharide, $J$. Colloid interface Sci., 30, 55-62 (2006).

9. A. LI, J. ZHANG, A. WANG, Utilization of starch and clay for the preparation of superabsorbent composite, Bioresour. Technol., 98, 327-333 (2007).

10. Y. CHEN, H.M. TAN, Crosslinked cmchitosan-poly(acrylate acid) as a novel super absorbent polymer, Polymer, 344, 887-896 (2006).

11. BARLEANY D.A., SOFIYATI, UNAYAH, ERIZAL, Aplikasi hidrogel superabsorben kopoli(asam akrilat-hidroksi etil akrilat)-kitosan hasil iradiasi gamma untuk adsorpsi ion logam $\mathrm{Cu}^{2+}$ dalam larutan, Jurnal Teknologi Pengelolaan Limbah, 16, 63-72 (2013).

12. M. ELLIOT, superabsorbent Polymers: $\mathrm{Http} / \mathrm{chmianet.zefat.ac.l1/download.}$ superabsorbant-polymers.pdf. Diakses tgl. 10 Maret 2015.

13. J.M. ROSIAK, P. ULANSKI, Synthesis of hydrogels by irradiation of polymers in aqueous solution, Radiat., Phys. Chem., 55, 139-151 (1999).

14. N. SHEIK, L. JALILI, F. ANVARI, A study on the pengembung behavior of poly(acrylic acid) hydrogels obtained by electron beam 
crosslinking, Radiat. Phys. Chem. 79, 735-739 (2010).

15. M.S. AHMED, Temperature effect on swelling properties of commmercial polyacrylic acid hydrogel beads, International Journal of Advanced Biological and Biomedical Research, 1, 1614-1637 (2013).

16. P. GUPTA, K. VERMANI, and S. GARG, Hydrogels from controlled release to $\mathrm{pH}$-responsive drug delivery, Drug Discovery Today, 7 (10), 569-579 (2002).

17. E. JABBARI, S. NOZARI, Swelling behavior of acrylic acid hydrogels prepared by $\gamma$ - radiation crosslinking of poly(acrylic acid) in aqueous solution. Eur. Polm. J. 36, 2685-2692 (2000).

18. A. KOSTIC, B. ADNADJEVIC, A. POPOVIC, J. JOVANOVIC, Comparison of the swelling kinetics of a partially neutralized poly(acrylic acid) hydrogel in distilled water and physiological solution, J. Serb. Chem. Soc. 72, 1139-1153 (2007).

19. A. CHAPIRO, "Radiation Chemistry of Polymeric System", 77-81 (1962).

20. J. LOISEAU, N. DOËRR, J.M. SUAU, J.B. EGRAZ, M.F. LLAURO,
LADAVIÈRE, Synthesis and characterization of poly(acrylic acid) produced by RAFT polymerization. Application as a very efficient dispersant of $\mathrm{CaCO}_{3}$, Kaolin, and $\mathrm{TiO}_{2}$, Macromolecules, 36 (9), 30663077 (2003).

21. ANONIM, http/en.wikipedia/wiki/ Tacticity, Diakses tgl. 14 April 2015.

22. ANONIM, www.masontechnology.ie./x/ usercom,Interpreting DSC curves part 1. Dynamic. measurements, diakses tgl. 14 April 2015.

23. K.S. ANEETH, A.S. ROBERT, N.A. PEPPAS, Effects of ionization on the reaction behavior and kinetics of acrylic acid polymerization, Macromolecules, 29, 8308-8312 (1996).

24. Z. TONG, X. LIU, Swelling equilibria and volume phase transition of partially neutralized poly/acrylic acid) gels, Eur. Polym. J. 29, 705-709 (1993).

25. R.S. TOMAR, I. GUPTA, R. SINGHAI, A.K. NAGPAL, Synthesis of poly(acrylamide co-acrylic acid)based superabsorbent hydrogels by gamma radiation: study of swelling behaviour and network parameters, Designed Monomers and Polym, 10, 49-66 (2007). 
Jurnal Ilmiah Aplikasi Isotop dan Radiasi

A Scientific Journal for The Applications of Isotopes and Radiation

ISSN 1907-0322

Vol. 11 No. 1 Juni 2015

\section{7-0322}

